\title{
Upstream expansion of round goby (Neogobius Melanostomus) - first record in the upper reaches of the Elbe river
}

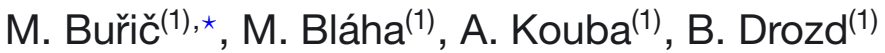 \\ Received September 8, 2015 \\ Revised October 19, 2015
}

Accepted October 23, 2015

Key-words:

biological

invasions,

fish,

Gobiidae, freshwater, barcoding

\section{ABSTRACT}

The round goby Neogobius melanostomus (Pallas, 1814) is one of the most problematic invasive fish species in recent years in Europe. It has proliferated from its native Ponto-Caspian region to several European river systems including their mouths and coastal brackish waters and was also introduced to and became widely established in the Great Lakes in North America. Despite recent reports about further invasions of round goby in the Odra and Vistula Rivers, including penetration of Baltic and North Seas, in the Elbe River this species was only recorded near its mouth close to Hamburg. Here we report the occurrence of round goby $622 \mathrm{~km}$ upstream from the previous record in Geesthacht (Germany) in the upper part of the Elbe River in Usti nad Labem (Czech Republic). This report illustrates the fast spread of round goby through several possible pathways, but the most certain is an introduction in ballast water.

\section{RÉSUMÉ}

L'expansion amont du gobie à taches noires (Neogobius melanostomus) - premier enregistrement dans le cours supérieur de la rivière Elbe

Mots-clés:
invasions
biologiques,
poisson,
Gobiidae,
eau douce,
code barres

Le gobie à taches noires Neogobius melanostomus (Pallas 1814) est l'une des espèces les plus problématiques envahissantes de poissons au cours des dernières années en Europe. II a proliféré depuis sa région natale pontocaspienne dans plusieurs systèmes fluviaux européens, y compris leurs estuaires et les eaux côtières saumâtres. II a également été introduit et est devenu largement établi dans les Grands Lacs en Amérique du Nord. Malgré de récents rapports sur de nouvelles invasions de gobie à taches noires dans les rivières Oder et Vistule, et sa pénétration des Mers du Nord et Baltique, dans l'Elbe, cette espèce n'a été enregistrée que près de son embouchure près de Hambourg. Nous rapportons ici l'apparition du gobie à taches noires dans la partie supérieure de l'Elbe à Usti nad Labem (République tchèque), $622 \mathrm{~km}$ en amont de l'enregistrement précédent à Geesthacht (Allemagne). Cette note illustre la propagation rapide du gobie à taches noires par plusieurs voies possibles, mais la plus probable est une introduction dans l'eau de ballast.

(1) University of South Bohemia in Ceske Budejovice, Faculty of Fisheries and Protection of Waters, South Bohemian Research Center of Aquaculture and Biodiversity of Hydrocenoses, Zátiší 728/II, 38925 Vodòany, 
The round goby Neogobius melanostomus (Pallas, 1814) is native to the Ponto-Caspian region, including the Black, Azov and Caspian Seas (Roche et al., 2013; Wolter and Roehr, 2010). Today the round goby is established in many European river systems, including brackish coastal waters near the river mouths (Czugala and Wozniczka, 2010; Hempel and Thiel, 2013). It was even introduced and is widely established in the Laurentian Great Lakes (Charlebois et al., 2001; Vanderploeg et al., 2002). Round goby can affect freshwaters as well as brackish ecosystems by its high invasive potential, including high reproductive effort, aggressiveness, high foraging activity and, among others, its role as a vector of parasites (Hempel and Thiel, 2015; Horkova and Kovac, 2014; Ondrackova et al., 2015; Vanderploeg et al., 2002). On the other hand, round goby can represent a significant part of the diet of other fish (Hensler et al., 2008; Vanderploeg et al., 2002). However, the negative effects undoubtedly prevail significantly.

Recent reports about round goby occurrence in Europe usually describe the deeper upstream penetration of rivers (Grabowska et al., 2010; Roche et al., 2013). In the case of the Elbe River, round goby was confirmed only near the river mouth in Hamburg and several kilometers upstream in Geesthacht (Hempel and Thiel, 2013). The further spreading of round goby was expected, but surprisingly not so far detected. Here, we report the discovery of a round goby juvenile $622 \mathrm{~km}$ upstream from the nearest known locality in Geesthacht (Figure 1). This specimen (standard length $=57 \mathrm{~mm}$, weight $4.9 \mathrm{~g}$ ) was accidentally caught (August 17th 2015) during sampling of zoobenthos in that part of the Elbe River close to Usti nad Labem (50.65697N, 14.04475E). There are also reports from local fishermen (Kava, 2015) about the occurrence of round goby at this site.

The caught individual was assigned to species according to morphological traits and confirmed by comparison of mitochondrial cytochrome $c$ oxidase gene fragment (COI) using BLAST and its web server (http://blast.ncbi.nlm.nih.gov/Blast.cgi). Applied molecular methods and primers for $\mathrm{COI}$ are described in Patoka et al. (2015). The amplified COI fragment (663 bp) completely matches haplotypes published at GenBank, acc. numbers: KR477072-73 (Upper Austrian Danube, Thalinger et al., 2015) and JX473740-41 - (Stepien and Tumeo, 2006).

As mentioned above, further expansion of round goby has been expected, because of its history of invasion not only in European water systems but also its introduction, establishment and expansion in North America (Czugala and Wozniczka, 2010; Horkova and Kovac, 2014; Pettitt-Wade et al., 2015; Roche et al., 2013). Several ways have been outlined as a possible source of newly detected round goby population in Elbe river: (1) upstream migration from the coastal part of the Elbe River (Hempel and Thiel, 2013); (2) migration through the canals connecting Elbe and Oder Rivers (through the system of canals of the Spree and Havel Rivers) which were also successfully invaded (Grabowska et al., 2010); (3) transport in ballast waters used in shipping; (4) unintentional transport by anglers using round goby as a bait; (5) unintentional introduction by fishermen or aquarists; and (6) transport of juvenile fish or fertilized eggs by other organisms e.g. birds (attached to the feathers or in throat pouch). All these mentioned possibilities can act concurrently. The most probable is transport of eggs, juveniles or adults in ballast waters and their release near to the Strekov sluice in Usti nad Labem, and subsequent successful establishment which could lead to further downstream migrations of juveniles and adults as well as downstream drifting of early life stages (Janac et al., 2013). With the increase of the population density in the Czech part of Elbe River, future expansion of round goby is expected, not only in a downstream direction but also upstream through possible further transportation in ballast waters. Similar pathways are generally the simplest gateway for biological invasions in inland and coastal waters due to continuing efforts to connect the large river systems (as well as sea basins) by canals enabling ship transportation. In the Elbe River, round goby have had to overcome during a few years (2-5 years) a distance of hundreds of kilometers (ca. 500-600 river kilometers).

In conclusion, the real origin of round goby caught in the upper Elbe River still remains unclear. However, with much current research activity in aquatic invasions the possible source of this invasion can probably be indicated soon. Future ecological studies of round 


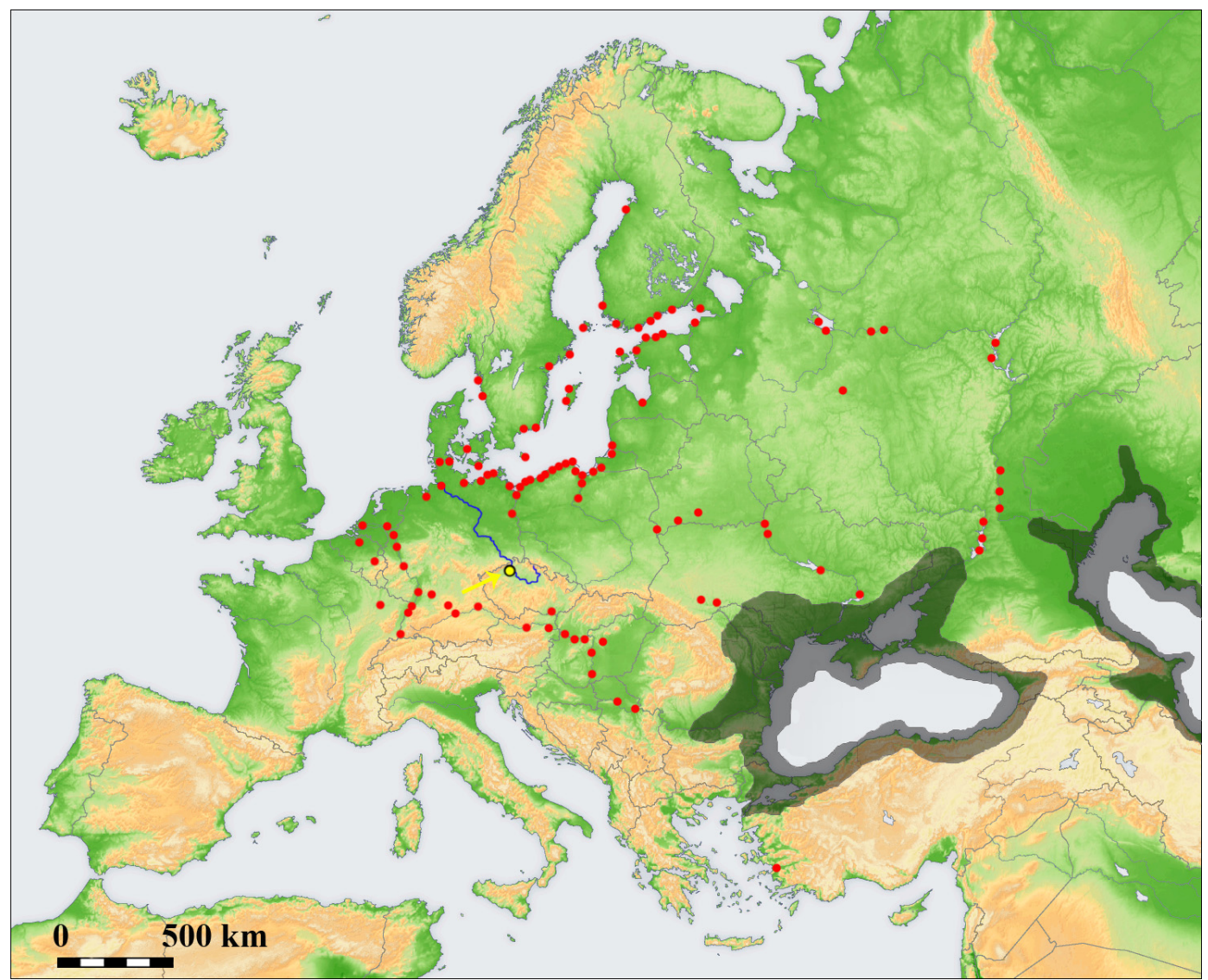

\section{Figure 1}

The summary map describes the distribution of round goby (Neogobius melanostomus, Pallas 1814) in Europe. Red dots represent the places of non-natural distribution, presumed native range is highlighted in grey (Eryilmaz, 2002; Jurajda et al., 2005; Verreycken et al., 2011; Kornis et al., 2012; Hempel and Thiel, 2013; Manné et al., 2013; Janac et al., 2013). The yellow dot (highlighted by yellow arrow) represents the newly confirmed locality of round goby occurrence at the upper Elbe River (blue coloured). The source map is licensed under the Creative Commons Attribution-Share Alike 3.0 Unported license. the original version of the map is available at the web site: https://commons. wikimedia.org/wiki/File:Europe topography_map_en.png).

goby, supplemented by recent papers discussing its European phylogeography (Brown and Stepien, 2008; Mombaerts et al., 2014), are required to estimate real migration abilities of this species and the role of humans in its spread.

\section{ACKNOWLEDGEMENTS}

The work was supported by the Ministry of Education, Youth and Sports of the Czech Republic - projects "CENAKVA" (No. CZ.1.05/2.1.00/01.0024) and "CENAKVA II" (No. LO1205 under the NPU I programm). We also deeply appreciate the assistance of prof. Julian Reynolds during writing and language editing of the manuscript.

\section{REFERENCES}

Brown J.E. and Stepien C.A., 2008. Ancient divisions, recent expansions: phylogeography and population genetics of the round goby Apollonia melanostoma. Mol. Ecol., 17, 2598-2615.

Charlebois P.M., Corkum L.D., Jude D.J. and Knight C., 2001. The round goby (Neogobius melanostomus) invasion: Current research and future needs. J. Gt. Lakes Res., 27, 263-266. 
Czugala A. and Wozniczka A., 2010. The River Odra estuary - another Baltic Sea area colonized by the round goby Neogobius melanostomus Pallas, 1811. Aquat. Invasions, 5, S61-S65.

Eryilmaz L., 2002. A new fish record for the Aegean Sea: round goby Neogobius melanostomus (Pallas, 1814) (Gobiidae). Israel J. Zool., 48, 251-252.

Grabowska J., Kotusz J. and Witkowski A., 2010. Alien invasive fish species in Polish waters: an overview. Folia Zool., 59, 73-85.

Hempel M. and Thiel R., 2013. First records of the round goby Neogobius melanostomus (Pallas, 1814) in the Elbe River, Germany. Biolnvasions Records, 2, 291-295.

Hempel M. and Thiel R., 2015. Effects of salinity on survival, daily food intake and growth of juvenile round goby Neogobius melanostomus (Pallas, 1814) from a brackish water system. J. Appl. Ichthyol., 31, 370-374.

Hensler S., Jude D. and He J., 2008. Burbot growth and diets in lakes Michigan and Huron: An ongoing shift from native species to round gobies. In: Paragamian V. and Bennett D. (eds.). Burbot: Ecology, Management and Culture. American Fisheries Society, Anchorage, pp. 91-107.

Horkova K. and Kovac V., 2014. Different life-histories of native and invasive Neogobius melanostomus and the possible role of phenotypic plasticity in the species' invasion success. Knowl. Manag. Aquatic Ecosyst., 412, 01.

Janac M., Slapansky L., Valova Z. and Jurajda P., 2013. Downstream drift of round goby (Neogobius melanostomus) and tubenose goby (Proterorhinus semilunaris) in their non-native area. Ecol. Freshw. Fish, 22, 430-438.

Jurajda P., Cerny J., Polacik M., Valova Z., Janac M., Blazek R. and Ondrackova M., 2005. The recent distribution and abundance of non-native Neogobius fishes in the Slovak section of the River Danube. J. Appl. Ichthyol., 21, 319-323.

Kava T., 2015. Nový druh ryby v severočeském Labi - hlaváččernoústý. http://www.crsusti.cz/cs/ aktuality, updated at 4th September 2015.

Kornis M.S., Mercado-Silva, N. and Vander Zanden, M.J., 2012. Twenty years of invasion: A review of round goby Neogobius melanostomus biology, spread and ecological implications. J. Fish Biol., $80,235-285$.

Manné S., Poulet N. and Dembski S., 2013. Colonisation of the Rhine basin by non-native gobiids: an update of the situation in France. Knowl. Manag. Aquat. Ecosyst., 411, 02.

Mombaerts M., Verreycken H., Volckaert F.A.M. and Huyse T., 2014. The invasive round goby Neogobius melanostomus and tubenose goby Proterorhinus semilunaris: two introduction routes into Belgium. Aquat. Invasions, 9, 305-314.

Ondrackova M., Hudcova I., Davidova M., Adamek Z., Kasny M. and Jurajda P., 2015. Non-native gobies facilitate the transmission of Bucephalus polymorphus (Trematoda). Parasites Vectors, 8, 382.

Patoka J., Bláha M. and Kouba A., 2015. Cherax (Cherax) subterigneus, a new crayfish (Decapoda: Parastacidae) from West Papua, Indonesia. J. Crust. Biol., 35, 831-838.

Pettitt-Wade H., Wellband K.W., Heath D.D. and Fisk A.T., 2015. Niche plasticity in invasive fishes in the Great Lakes. Biol. Invasions, 17, 2565-2580.

Roche K.F., Janac M. and Jurajda P., 2013. A review of Gobiid expansion along the Danube-Rhine corridor - geopolitical change as a driver for invasion. Knowl. Manag. Aquat. Ecosyst., 416, 33.

Stepien C.A. and Tumeo M.A., 2006. Invasion genetics of Ponto-Caspian gobies in the Great Lakes: a 'cryptic' species, absence of founder effects, and comparative risk analysis. Biol. Invasions, 8, 61-78.

Thalinger B., Oehm J., Mayr H., Obwexer A., Zeisler C. and Traugott M., 2015. Molecular prey identification in Central European piscivore. Mol. Ecol. Resour., in press, DOI: 10.1111/1755-0998.12436.

Vanderploeg H.A., Nalepa T.F., Jude D.J., Mills E.L., Holeck K.T., Liebig J.R., Grigorovich I.A. and Ojaveer $\mathrm{H}$., 2002. Dispersal and emerging ecological impacts of Ponto-Caspian species in the Laurentian Great Lakes. Can. J. Fish. Aquat. Sci., 59, 1209-1228. 
Verreycken H., Breine J.J., Snoeks J. and Belpaire C., 2011. First record of the round goby, Neogobius melanostomus (Actinopterygii: Perciformes: Gobiidae) in Belgium. Acta Ichthyol. Piscat., 41, $137-140$.

Wolter C. and Roehr F., 2010. Distribution history of non-native freshwater fish species in Germany: how invasive are they? J. Appl. Ichthyol., 26, 19-27.

Cite this article as: M. Buřič, M. Bláha, A. Kouba and B. Drozd, 2015. Upstream expansion of round goby (Neogobius Melanostomus) - first record in the upper reaches of the Elbe river. Knowl. Manag. Aquat. Ecosyst., 416, 32. 